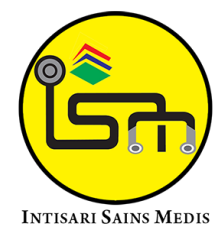

Published by Intisari Sains Medis

\title{
Strabismus sebagai komplikasi pemasangan sclera buckle pada ablasio retina regmatogen: laporan kasus
}

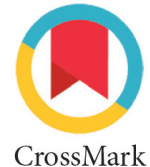

CrossMark

1PPDS-1 IImu Kesehatan Mata, Fakultas Kedokteran Universitas Udayana, RSUP Sanglah Denpasar, Bali, Indonesia;

${ }^{2}$ Departement IImu Kesehatan Mata, Fakultas Kedokteran Universitas Udayana, RSUP Sanglah Denpasar, Bali, Indonesia;

\section{*Korespondensi:}

Pande Putu Adityo Ananta Ardika; PPDS-1 IImu Kesehatan Mata, Fakultas Kedokteran Universitas Udayana, RSUP Sanglah Denpasar, Bali, Indonesia;

pandeadityo@gmail.com

\author{
Pande Putu Adityo Ananta Ardika ${ }^{1 *}$, Ari Andayani ${ }^{2}$, Ni Made Ayu Surasmiati ${ }^{2}$, \\ Ni Made Ari Suryathi' ${ }^{2}$ I Made Agus Kusumadjaja ${ }^{2}$
}

\section{ABSTRACT}

Introduction: Sclera buckle is one of the operative management of rhegmatogenous retinal detachment. Sclera buckle can combine with vitrectomy in young people, phakic, myopia more than 6 dioptri, axial length more than $26 \mathrm{~mm}$, proliferative vitreoretinopathy stage $C$, multiple inferior break and recurrent break. Complications from the installation of sclera buckle is one of them the occurrence of strabismus after the installation of sclera buckle. Treatment can be done to remove the sclera buckle and further surgery for extraocular muscle.

Case Description: Male patients aged 31 years, patients present with complaints right eyes rolling inward since 8 months ago. The patient had a history of surgical sclera buckle and tamponade with silicone oil. Patient also complain blurry vision since 1 month ago after removing silicone oil. The patient has a history of -5.00 glasses in both eyes. In examination obtained Hirschberg esotropia 15 degrees and retinal detachment on right eyes. Patient was diagnosed with right eye Detached Retina post evacuation of silicone oil (16 days), acquired esotropia Suspect et cause sclera buckle installation. Patients are planned to undergo

Re-Vitrectomy Pars Plana (VPP), Release Sclera Buckle, Endolaser, Silicon Oil tamponade, and evaluation of extraocular muscle at surgery. During evaluation of extraocular muscle there was fibrosis cover four rectus muscle and no tear was found. Then we removed of fibrosis and released sclera buckle. Strabismus complaint did not feel better after removed of fibrosis so we planned for further action was medial rectus recess with adjustable suture.

Conclusion: Sclera buckle can combine with vitrectomy on young people, phakic, myopia more than 6 dioptri, axial length more than $26 \mathrm{~mm}$, proliferative vitreoretinopathy, multiple inferior break and recurrent break. Installation of sclera buckle can cause complications in the form of postoperative strabismus. One of the causes of this complication is fibrosis of the extraocular muscles, so there is an attachment called fat adherent syndrome. Treatment that can be taken to treat strabismus after sclera buckle surgery is one of them with the release of sclera buckle, but if strabismus complaints did not improve, surgery can be done on extraocular muscles to improve the position of the ball.

Keywords: rhegmatogenous retinal detachment, vitrectomy pars plana, sclera buckle, fibrosis, strabismus.

Cite This Article: Ardika, P.P.A.A., Andayani, A., Surasmiati, N.M.A., Suryathi, N.M.A., Kusumadjaja, I.M.A. 2021. Strabismus sebagai komplikasi pemasangan sclera buckle pada ablasio retina regmatogen: laporan kasus. Intisari Sains Medis 12(3): 848-856. D0I: 10.15562/ism.v12i3.1177

\section{ABSTRAK}

Pendahuluan: Sclera buckle merupakan salah satu tindakan operatif dalam menangani ablasio retina regmatogen. Tindakan sclera buckle dapat dikombinasikan dengan vitrektomi pada orang muda, phakia, riwayat miopia lebih dari 6 dioptri, panjang bola mata lebih dari 26 milimeter, ditemukan adanya proliferatif vitreoretinopati stadium C, robekan multiple pada bagian inferior retina dan robekan berulang. Komplikasi dari pemasangan sclera buckle ini adalah salah satunya terjadinya strabismus pasca pemasangan sclera buckle. Penanganan yang dapat dilakukan berupa pelepasan sclera buckle, dan operasi strabismus jika kondisi otot ekstraokular tidak membaik.

Deskripsi Kasus: Pasien laki-laki, usia 31 tahun, datang dengan keluhan mata kanan bergulir ke dalam sejak 8 bulan yang lalu. Keluhan dirasakan setelah pasien melakukan operasi pemasangan sclera buckle dan silicon oil 8 bulan yang lalu. Saat ini pasien juga mengeluhkan pandangan kabur yang sudah dirasakan sejak 1 bulan yang lalu setelah dilakukan pengangkatan silicon oil. Pada pemeriksaan ditemukan Hirschberg esotropia 15 derajat dan ditemukan ablasio retina pada mata kanan. Pasien didiagnosis dengan okuli dekstra rekuren ablasio retina pasca pengeluaran silicon oil 
(16 hari), dan kecurigaan esotropia didapat (acquired esotropia) ec pasca pemasangan sclera buckle. Pasien direncanakan untuk dilakukan Re-Vitrektomi Pars Plana (VPP), pelepasan sclera buckle, endolaser, retamponade silicon oil dan evaluasi otot ekstraokular durante operasi. Pada saat dilakukan evaluasi otot ekstraokular ditemukan adanya fibrosis pada keempat otot rektus dan tidak ditemukan adanya robekan pada otot ekstraokular. Kemudian dilakukan pembersihan dari fibrosis dan pelepasan dari sclera buckle. Keluhan strabismus tidak dirasakan membaik pasca dilakukan pembersihan fibrosis sehingga direncanakan untuk dilakukan tindakan lanjutan yaitu medial rectus reses dengan adjustable suture.

Simpulan: Tindakan sclerabuckle ini dapat dikombinasi dengan vitrektomi pada pasien muda, phakia, riwayat miopia tinggi lebih dari 6 dioptri, panjang bola mata lebih dari 26 milimeter, ditemukan adanya proliferatif vitreoretinopati, robekan multiple di bagian inferior retina dan robekan berulang. Pemasangan sclera buckle ini dapat menimbulkan komplikasi berupa strabismus pasca operasi. Penyebab dari terjadinya komplikasi ini salah satunya fibrosis pada otot ekstraokular sehingga terjadi perlekatan yang disebut dengan fat adheren syndrome. Tindakan yang dapat dilakukan untuk penanganan strabismus pasca operasi sclera buckle ini adalah salah satunya dengan pelepasan dari sclera buckle, namun apabila keluhan strabismus tidak membaik bisa dilakukan operasi pada otot ekstraokular untuk memperbaiki posisi bola mata.

Kata kunci: ablasio retina regmatogeno, vitrektomi pars plana, sclera buckle, fibrosis, strabismus.

Sitasi Artikel ini: Ardika, P.P.A.A., Andayani, A., Surasmiati, N.M.A., Suryathi, N.M.A., Kusumadjaja, I.M.A. 2021. Strabismus sebagai komplikasi pemasangan sclera buckle pada ablasio retina regmatogen: laporan kasus. Intisari Sains Medis 12(3): 848-856. D0I: 10.15562/ism.v12i3.1177

\section{PENDAHULUAN}

Sclera buckle merupakan salah satu tindakan operatif yang dilakukan untuk mengatasi ablasio retina regmatogen. Terjadi perdebatan dalam menentukan tindakan operasi yang terbaik dalam menangani ablasio retina regmatogen. ${ }^{1}$

Ablasio retina regmatogeno (ARR) adalah lepasnya lapisan saraf penglihatan dalam bola mata dari lapisan di bawahnya atau lapisan retina pigment epithelium (RPE) dengan akumulasinya cairan subretina. ${ }^{1}$ Kejadian ARR yaitu sekitar 1 dari 10.000 populasi normal. Kemungkinan ini meningkat pada pasien dengan myopia (40-50\%), pasca operasi katarak (30-40\%) dan trauma okuli (1020\%). Mengenai kedua mata kira2 10\%. Insiden nya terjadi pada umur 45 sampai 65 tahun tetapi bisa terjadi pada umur lebih muda jika terjadi pada penderita myopia yaitu dapat terjadi pada umur 2545 tahun. $^{2}$

Penentuan jenis tindakan pada ablasio retina regmatogen terdapat beberapa faktor, salah satunya keahlian dan pertimbangan dari operator. Apabila pada pasien muda, phakia, riwayat minus tinggi, ditemukan adanya proliferative vitreoretinopathy, robekan multiple pada bagian inferior retina, dan robekan berulang pada retina maka dapat dilakukan tindakan kombinasi antara pemasangan sclera buckle dan vitrektomi. ${ }^{3,4}$

Komplikasi dari pemasangan sclera buckle ini adalah salah satunya terjadinya strabismus pasca pemasangan sclera buckle. Insidensi strabismus pasca operasi sclera buckle adalah sebesar $4,65 \%$. Strabismus pasca operasi sclera buckle bisa terjadi akibat 4 mekanisme yaitu sensoris, mekanikal, muskular dan faktor anatomis. Terapi dalam terjadinya strabismus pasca pemasangan sclera buckle bisa berupa pelepasan dari sclera buckle maupun dengan melakukan operasi pada otot ekstraokular. Sampai saat ini belum terdapat rekomendasi terhadap penanganan yang tepat pada pasien strabismus pasca pemasangan scleral buckle. ${ }^{5}$

Penulis melaporkan kasus esotropia pasca pemasangan buckle pada pasien laki-laki 31 tahun dengan gejala awal mata kanan kabur dan bergulir ke dalam paska dilakukan operasi pemasangan sclera buckle akibat ablasio retina. Laporan kasus ini dibuat bertujuan untuk menambah wawasan pengetahuan dalam menegakkan diagnosis, melakukan pemeriksaan, dan pertimbangan tatalaksana pada kasus esotropia pada pasien pasca operasi sclera buckle agar dapat memberikan terapi yang tepat pada pasien tersebut.

\section{LAPORAN KASUS}

Pasien laki-laki, 31 tahun, datang ke Poliklinik Mata (8/1/2020) dengan keluhan penglihatan pada mata kanan kabur sejak 1 bulan yang lalu. Keluhan dirasakan mendadak setelah satu minggu dilakukan operasi pengangkatan silikon (26/12/2019) di salah satu rumah sakit pemerintah. Pasien memiliki riwayat operasi pemasangan sclera buckle dan vitrektomi dengan tamponade silicon oil di salah satu rumah sakit pemerintah pada bulan Maret 2019. Selain itu, pasien juga mengeluh mata kanan bergulir ke dalam dan pandangan double. Keluhan ini dirasakan pasien sudah sejak 8 bulan yang lalu satu minggu setelah dilakukan operasi pemasangan sclera buckle. Keluhan mata bergulir ke dalam ini dikatakan menetap. Pasien memiliki riwayat menggunakan kacamata minus -5.00 pada kedua mata. Pasien bekerja sebagai karyawan di salah satu bank swasta. Pasien mengatakan ibu pasien memiliki riwayat yang sama seperti pasien yaitu pernah operasi akibat retina lepas dan di keluarga juga memiliki riwayat mata minus tinggi. Riwayat penyakit sistemik disangkal oleh pasien.

Pada pemeriksaan oftalmologi didapatkan Hirschberg esotropia (ET) 15 derajat. Tajam penglihatan pada mata kanan $1 / 300$, sedangkan tajam penglihatan 
pada mata kiri 6/15 dan di pinhole tidak ada perbaikan dan jika menggunakan kacamata S - 5.00 tajam penglihatan menjadi 6/6. Pemeriksaan segmen anterior pada mata kanan didapatkan jahitan pada konjungtiva, ditemukan adanya conjunctiva vascular injection, dan pericorneal vascular injection, pada lensa didapatkan lensa intraokular sedangkan segmen anterior mata kiri dalam batas normal Gambar 1 dan 2. Pemeriksaan fundus pada mata kanan didapatkan nervus II bulat, batas tegas, cup to disc ratio (cdr) tidak dapat dievaluasi, ablasio retina, ditemukan jejas laser, dan tidak ada refleks makula. Sedangkan pemeriksaan fundus
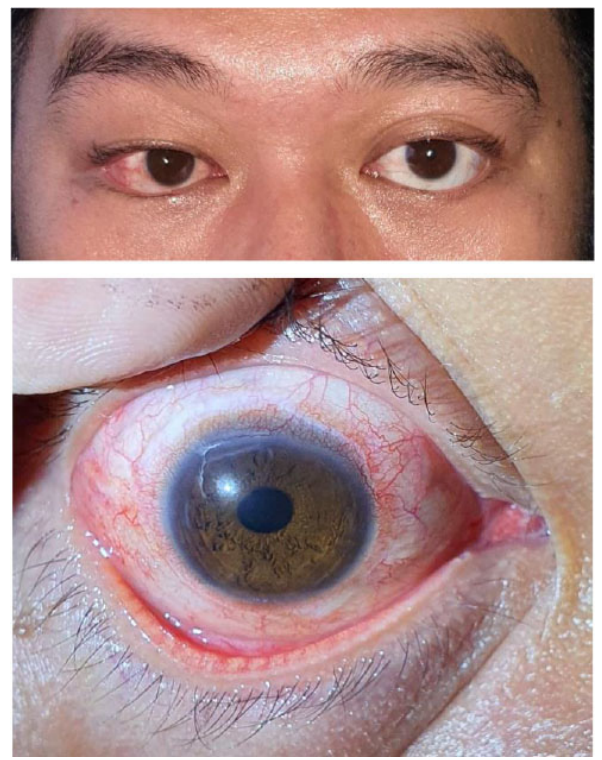

Gambar 1. Tampak Mata dari anterior Pra Operasi (Courtesy of Pande Adityo, 2020). pada mata kiri didapatkan papil N II bulat batas tegas, cdr $0,3, a a / v v 2 / 3$, retina tigroid, dan ditemukan refleks makula. Tekanan bola mata kedua mata normal. Pada pemeriksaan strabismus didapatkan krimsky 30 prisma dioptri Base Out, pada pemeriksaan cover/uncover ditemukan shifting ke lateral dengan fiksasi senter dan alternating cover test didapatkan tidak ada shifting, gerakan kedua bola mata baik ke segala arah. Pemeriksaan worth 4 dot test (WFDT) didapatkan supresi pada mata kanan. Pada pemeriksaan Forced Duction Test (FDT) ditemukan resktriksi kearah medial, sedangkan pada Forced Generation Test (FGT) tidak ditemukan adanya paresis.

Berdasarkan anamnesis dan pemeriksaan mata lengkap, pasien didiagnosis dengan mata kanan rekuren ablasio retina post evakuasi silikon oil (16 hari), paska pemasangan sclera buckle, dan esotropia didapat (acquired esotropia) ec paska pemasangan sclera buckle. Pasien direncanakan untuk dilakukan ReVitrektomi Pars Plana (VPP), pelepasan sclera buckle, endolaser, tamponade silicon oil dan evaluasi otot ekstraokular durante operasi pada mata kanan dengan bius umum.

Pasien dilakukan operasi pada tanggal 30 januari 2020, pada saat operasi ditemukan adanya jaringan fibrosis pada sclera buckle di bagian infero nasal dan dilakukan evaluasi keempat otot ditemukan adanya fibrosis pada otot, tidak ditemukan adanya ruptur atau robekan, kemudian dilakukan pembersihan
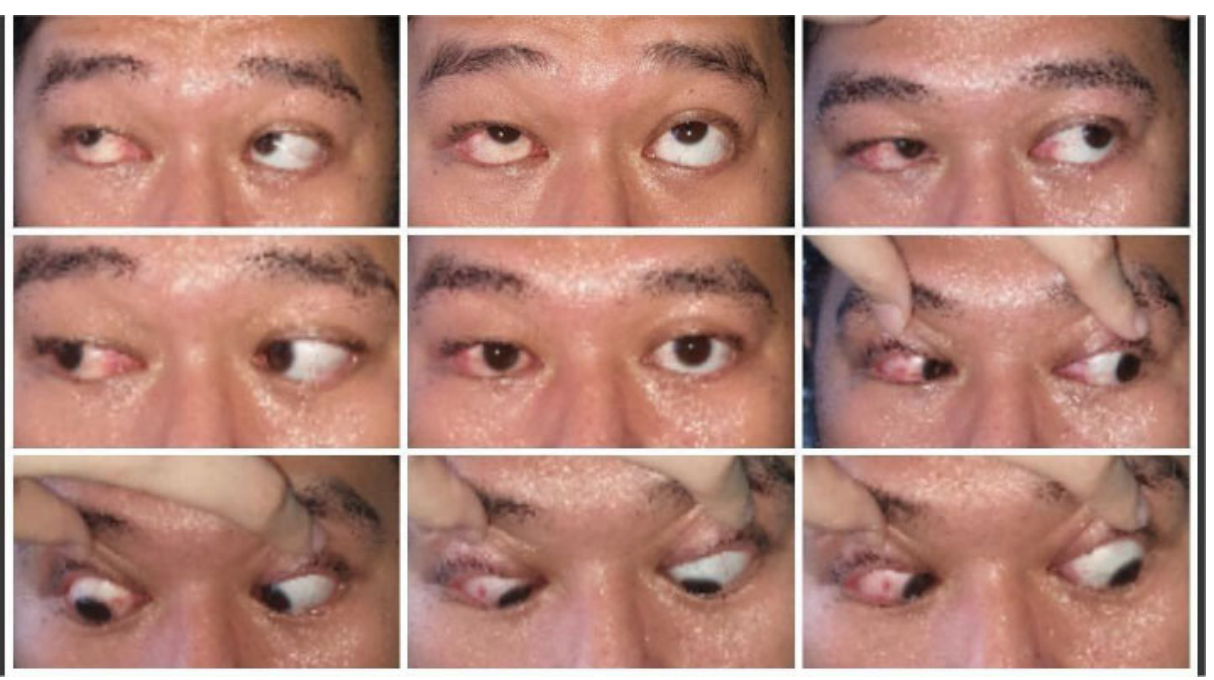

Gambar 2. Tampak nine gaze Pra Operasi. jaringan fibrosis pada keempat otot (Gambar 3-7).

Pada tanggal 31 januari 2020, satu hari pasca operasi vitrektomi, pelepasan sclera buckle dan evaluasi otot ekstraokular pada pasien didapatkan, Hirschberg ET 15 derajat tajam penglihatan pada mata kanan 1/300, sedangkan pada mata kiri 6/18 (dengan kacamata 6/6). Pemeriksaan segmen anterior pada mata kanan didapatkan jahitan pada konjungtiva, ditemukan conjunctival vascular injection, pericorneal vascular injection, dan subconjunctival bleeding, pada lensa didapatkan lensa intraokular sedangkan segmen anterior mata kiri dalam batas normal (Gambar 8 dan 9). Pemeriksaan fundus pada mata kanan didapatkan nervus II bulat, batas tegas, $c d r$ tidak dapat dievaluasi, retina attached, jejas laser, dan refleks makula menurun. Tekanan bola mata kedua mata normal. Pada pemeriksaan strabismus didapatkan krimsky 30 prisma dioptri Base Out, pada pemeriksaan cover/uncover ditemukan shifting ke lateral dengan fiksasi senter dan alternating cover test didapatkan tidak ada shifting, gerakan kedua bola mata baik ke segala arah. Pasien didiagnosis dengan mata kanan pseudofakia, reattached retina, SO filled eye (pasca pelepasan sclera buckle, vitrectomy pars plana, endolaser, endodiathermy, tamponade dengan silikon oil $13005 \mathrm{cc}$, eksplorasi dan pelepasan fibrosis ec esotropia didapat (acquired esotropia) hari ke 1. Mendapatkan terapi tidur tengkurap miring kanan, tetes mata levofloxacin sebanyak 1 tetes tiap 4 jam pada mata kanan, tetes mata Metil prednisolon 1 tetes tiap 4 jam mata kanan, dan Paracetamol tablet $500 \mathrm{mg}$ tiap 8 jam sehari.

Pasien kembali datang kontrol tanggal 5 Februari 2020, dan mengeluh penglihatan mata kanan masih kabur dan double. Pada pemeriksaan oftalmologi didapatkan tajam penglihatan pada mata kanan 2/60 dengan pinhole tidak maju; sedangkan tajam penglihatan pada mata kiri 6/18 dan maju dengan menggunakan pinhole 6/6. Pemeriksaan segmen anterior pada mata kanan didapatkan jahitan pada konjungtiva, ditemukan conjunctival vascular injection, pericorneal vascular injection, dan subconjunctival bleeding, Pemeriksaan fundus pada mata kanan 
didapatkan nervus II bulat, batas tegas, cdr tidak dapat dievaluasi, retina attached, jejas laser, dan ditemukan refleks makula menurun (Gambar 10 dan 11). Tekanan bola mata kedua mata normal. Pada
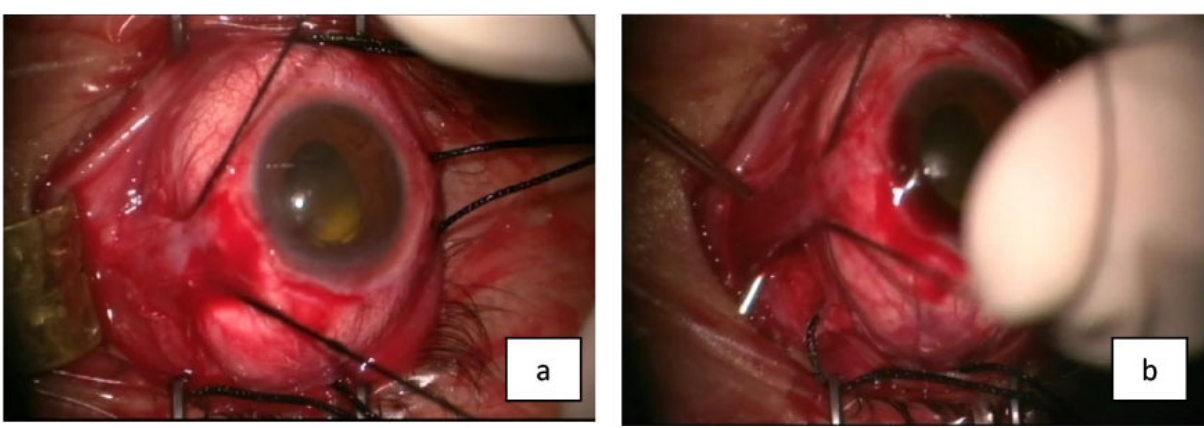

Gambar 3. (foto a) Foto fibrosis pada rektus medial, (foto b) foto fibrosis sudah dibersihkan.
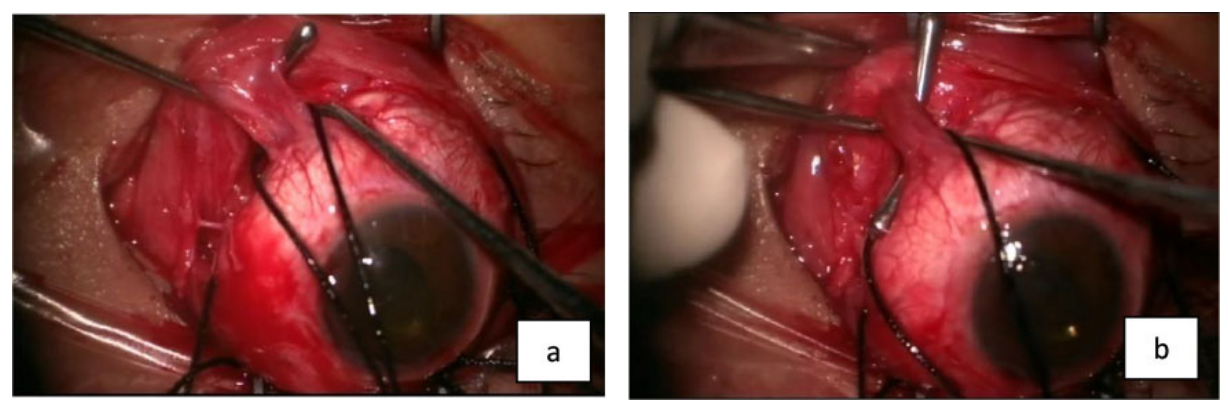

Gambar 4. (foto a) Foto fibrosis pada rektus inferior, (foto b) foto fibrosis sudah dibersihkan.
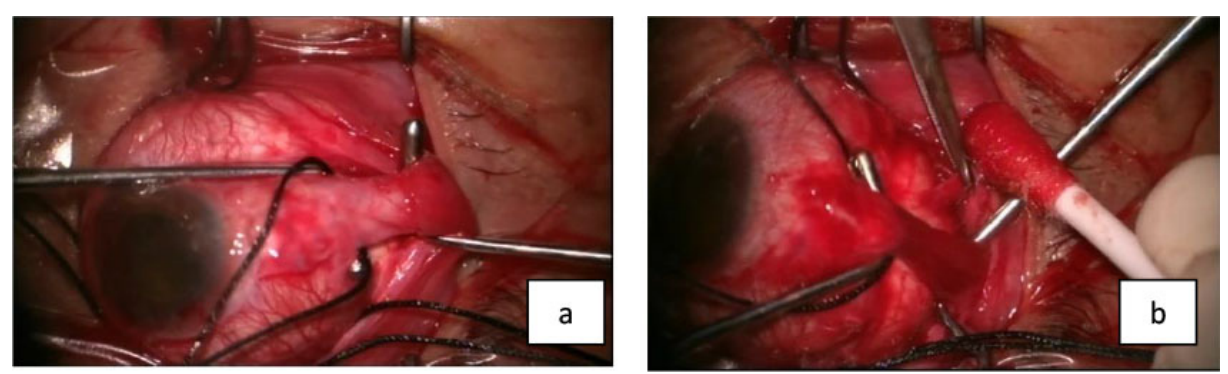

Gambar 5. (foto a) Foto fibrosis pada rektus temporal, (foto b) foto fibrosis sudah dibersihkan.
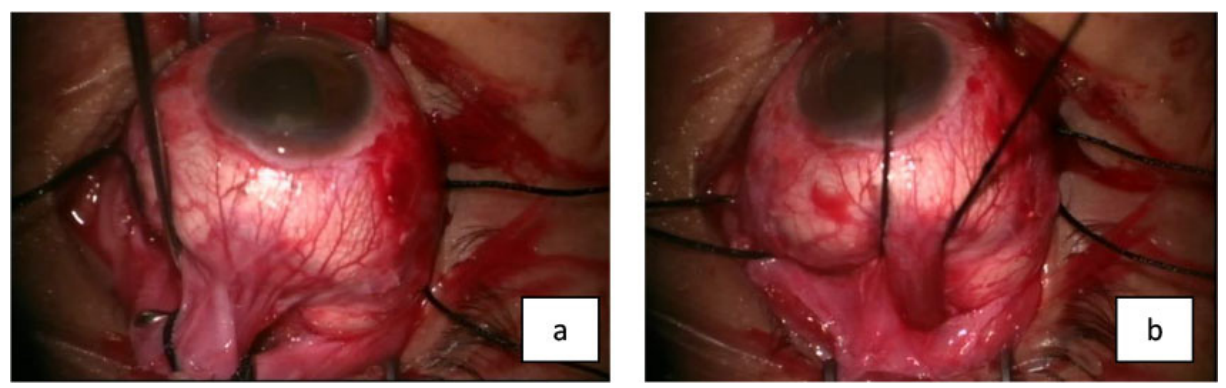

Gambar 6. (foto a) Foto fibrosis pada rektus superior, (foto b) foto fibrosis sudah dibersihkan. test didapatkan tidak ada shifting, gerakan kedua bola mata baik ke segala arah. Pasien di diagnosis dengan OD pseudofakia, reattached retina, SO filled eye (post release sclera buckle, VPP, endolaser, endodiathermy, tamponade silicon oil $13005 \mathrm{cc}$, eksplorasi dan release fibrosis ec esotropia didapat (acquired esotropia)) hari ke 5. Dari divisi retina mendapatkan terapi tetes mata levofloxacin sebanyak 1 tetes tiap 4 jam pada mata kanan, Metil prednisolon 1 tetes tiap 4 jam mata kanan, metilprednisolone tablet $12 \mathrm{mg}$ tiap 8 jam, paracetamol $500 \mathrm{mg}$ tablet tiap 8 jam, Dari divisi strabismus di diagnosis dengan mata kanan post eksplorasi, pelepasan fibrosis et causa esotropia didapat (acquired esotropia) et causa pasca pemasangan sclera buckle dan direncanakan untuk dilakukan operasi kembali dengan OD pro Medial Rectus Recess dengan adjustable suture.

Pada tanggal 29 Maret 2020 pasien kembali datang kontrol dan mengeluh penglihatan mata kanan masih kabur. Pada pemeriksaan oftalmologi didapatkan tajam penglihatan pada mata kanan 1/300. Hirschberg ET 15 derajat. Pemeriksaan segmen anterior pada mata kanan didapatkan conjunctival vascular injection minimal. Pemeriksaan fundus pada mata kanan didapatkan nervus II bulat, batas tegas, $c d r$ tidak dapat di evaluasi, rekuren ablasio retina pada arah jam 9 sampai 12, jejas laser, dan tidak ditemukan refleks makula. Sedangkan pemeriksaan fundus pada mata kiri didapatkan nervus II bulat batas tegas, $c d r 0,3$, aa/vv $2 / 3$, retina tigroid, dan ditemukan refleks makula. Tekanan bola mata kedua mata normal. Pasien didiagnosis dengan mata kanan pseudofakia, SO filled eye, dan rekuren ablasio retina. Pasien direncanakan untuk dilakukan Re-vitrektomi pars plana kedua pada mata kanan dengan bius umum pada tanggal 30 Maret 2020.

Tanggal 31 maret 2020 satu hari paska dilakukannya operasi vitrektomi yang kedua pada pasien didapatkan, Hirschberg ET 15 derajat tajam penglihatan pada mata kanan 1/300. Pemeriksaan segmen anterior pada mata kanan didapatkan bekas jahitan pada konjungtiva, conjunctival vascular injection, pericorneal vascular injection, dan subconjunctival bleeding (Gambar 12). Pemeriksaan fundus pada mata kanan 
didapatkan nervus II bulat, batas tegas, $c d r$ tidak dapat dievaluasi, retina attached, jejas laser, dan refleks makula menurun. Tekanan bola mata kedua mata normal. Pasien didiagnosis dengan mata kanan pseudofakia, retina attached, SO filled eye (paska tindakan vitrectomy pars plana, endodiathermy, endolaser, dan tamponade silicon oil $13005 \mathrm{cc}$ ) hari pertama. Pasien mendapatkan terapi ciprofloxacin tablet tiap 12 jam, paracetamol $500 \mathrm{mg}$ tiap 8 jam, levofloxacin tetes mata 1 tetes tiap 4 jam mata kanan, tetes mata metil prednisolon 1 tetes tiap 4 jam mata kanan, tetes mata artificial eye tears 1 tetes tiap 4 jam pada kedua mata, tidur tengkurap dan kontrol kembali 2 minggu.

Tanggal 14 april 2020, pasien datang kontrol dan mengeluhkan kabur pada mata kanan. Hirschberg ET 15 derajat tajam penglihatan pada mata kanan 1/300. Pemeriksaan segmen anterior pada mata kanan didapatkan pada konjungtiva tenang, pada lensa didapatkan lensa intraokular sedangkan segmen anterior mata kiri dalam batas normal. Pemeriksaan fundus pada mata kanan didapatkan nervus II bulat, batas tegas, $c d r$ sde, retina attached, jejas laser, dan refleks makula menurun. Tekanan bola mata kedua mata normal. Pasien didiagnosis dengan mata kanan pseudofakia, retina attached, SO filled eye (pasca tindakan vitrectomy pars plana, endodiathermy, endolaser dan tamponade silicon oil $13005 \mathrm{cc}$ ) hari ke- 14 . Pasien mendapatkan terapi levofloxacin tetes mata 1 tetes tiap 4 jam mata kanan, metil prednisolon tetes mata 1 tetes tiap 4 jam mata kanan, artificial eye tears tetes mata 1 tetes tiap 4 jam pada kedua mata, tidur telungkup, kontrol 2 minggu.

Tanggal 7 Juli 2020 pasien kembali kontrol dengan tetap mengeluhkan kabur pada mata kanan. Hirschberg ET 15 derajat dengan tajam penglihatan mata kanan LPGP, sedangkan pada mata kiri 6/18 (dengan kacamata 6/6). Pada lensa mata kanan ditemukan adanya lensa intraokular dan pada pemeriksaan fundus mata kanan ditemukan adanya nervus II bulat, batas tegas, $c d r$ sde, retina attached, jejas laser, dan refleks makula menurun. Pasien didiagnosis dengan mata kanan pseudofakia, retina attached, SO filled eye (pasca tindakan vitrectomy pars plana, endodiathermy, endolaser dan tamponade

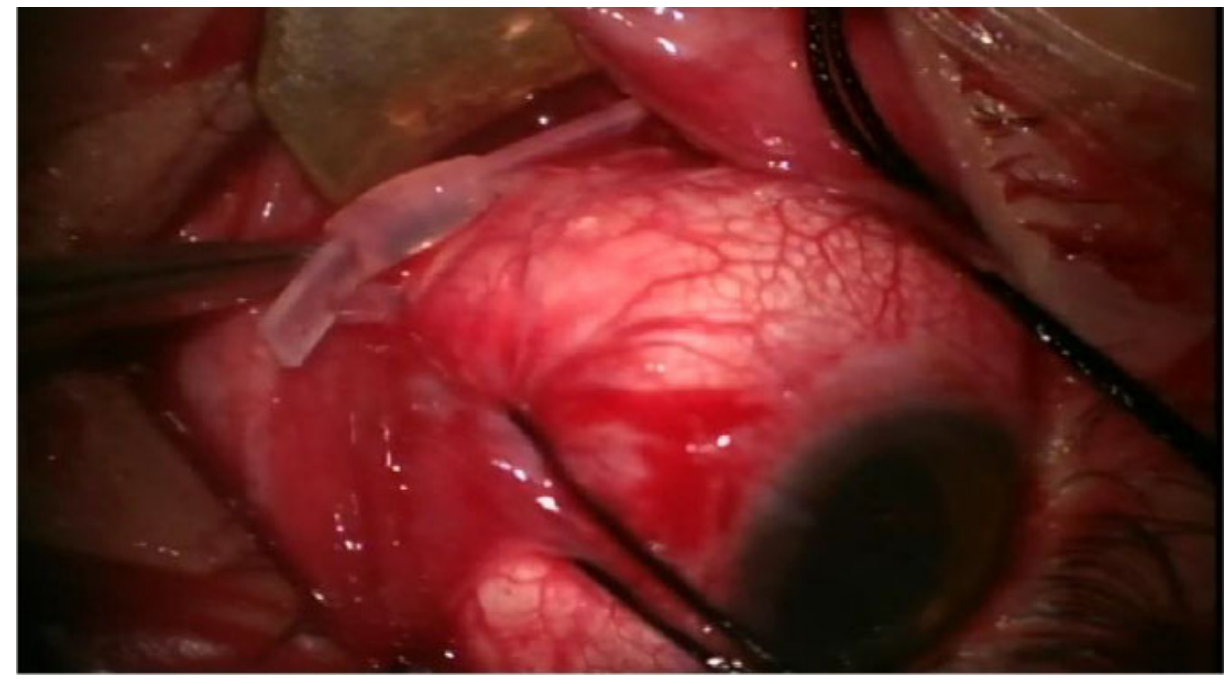

Gambar 7. Posisi band dari sclera buckle pada pasien.

silicon oil $13005 \mathrm{cc}$ ) bulan ke-4 (Gambar 13 dan 14). Pasien direncanakan untuk dilakukan pengeluran tamponade silicon oil pada mata kanan dengan bius umum. Dari divisi strabismus didapatkan pemeriksaan krimsky 25 prisma dioptri base out, pemeriksaan cover/uncover ditemukan shifting ke lateral dengan fiksasi senter, dan gerakan bola mata baik ke segala arah. kemudian pasien didiagnosis dengan esotropia didapat (acquired esotropia) et causa pasca pemasangan sclera buckle pada mata kanan dan direncanakan untuk dilakukan tindakan reses rectus medial + adjustable suture pada mata kanan dengan bius umum setelah dilakukan pengeluaran tamponade silicon oil.

Tanggal 23 Desember 2020 pasien dilakukan tindakan operasi OD Reses Rektus Medial + Adjustable Suture dan didapatkan Hirschberg pasca operasi ET 10 derajat (gambar 15). Tajam penglihatan mata kanan LPGP, sedangkan pada mata kiri 6/18 (dengan kacamata 6/6). Pemeriksaan strabismus didapatkan pemeriksaan krimsky 15 prisma dioptri base out, pemeriksaan cover/uncover ditemukan tidak ditemukan shifting, dan gerakan bola mata baik ke segala arah.

\section{DISKUSI}

Sclera buckle merupakan salah satu tindakan operatif yang dilakukan untuk mengatasi ablasio retina regmatogen sejak 60 tahun yang lalu. Sejak dua dekade terakhir sudah ditemukan tindakan lainnya yaitu pneumopeksi dan vitrektomi.
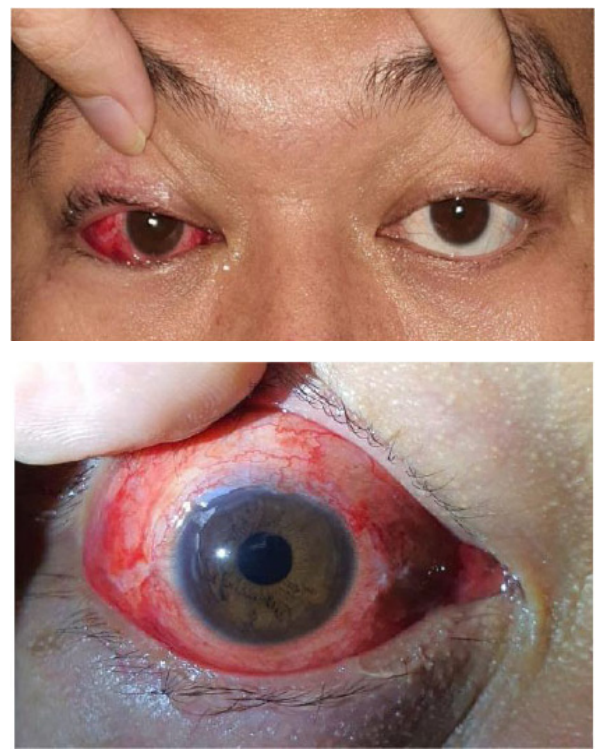

Gambar 8. Tampak Mata dari anterior Post Operasi.

Terjadi perdebatan dalam menentukan tindakan operasi yang terbaik dalam menangani ablasio retina regmatogen. ${ }^{1,6}$

Ablasio retina regmatogen adalah lepasnya lapisan saraf penglihatan dalam bola mata dari lapisan di bawahnya atau lapisan retina pigmen epitelium (RPE) dengan akumulasinya cairan subretina. Pada ablasio retina regmatogen (ARR) dimana ablasio terjadi akibat adanya robekan pada retina sehingga cairan masuk ke belakang antara sel pigmen epitel retina, dengan akibat retina terangkat dan terlepas dari lapisan pigmen epitel. Pada ablasio retina saraf penglihatan 
dalam bola mata lepas dari lapisan dibawahnya dengan akibat retina tidak dapat mengirimkan rangsangan cahaya ke otak sehingga penglihatan di daerah yang lepas akan terganggu. ${ }^{1}$ Kejadian ARR yaitu sekitar 1 dari 10.000 populasi normal. Kemungkinan ini meningkat pada pasien dengan myopia (40-50\%), pasca operasi katarak (30-40\%) dan trauma okuli (10-20\%). Mengenai kedua mata kira-kira $10 \%$. Insiden nya terjadi pada umur 45 sampai 65 tahun tetapi bisa terjadi pada umur lebih muda jika terjadi pada penderita myopia yaitu dapat terjadi pada umur 25- 45 tahun. Pada pasien dengan miopia tinggi, yang mencapai sekitar 2\% dari populasi, lebih mungkin untuk menderita penyakit mata tertentu seperti glaukoma atau katarak, dan lebih khusus yang berhubungan dengan retina yaitu ablasio retina, degenerasi retina sentral dan lainnya. Ablasio retina ditandai dengan adanya penurunan tajam penglihatan tanpa disertai rasa
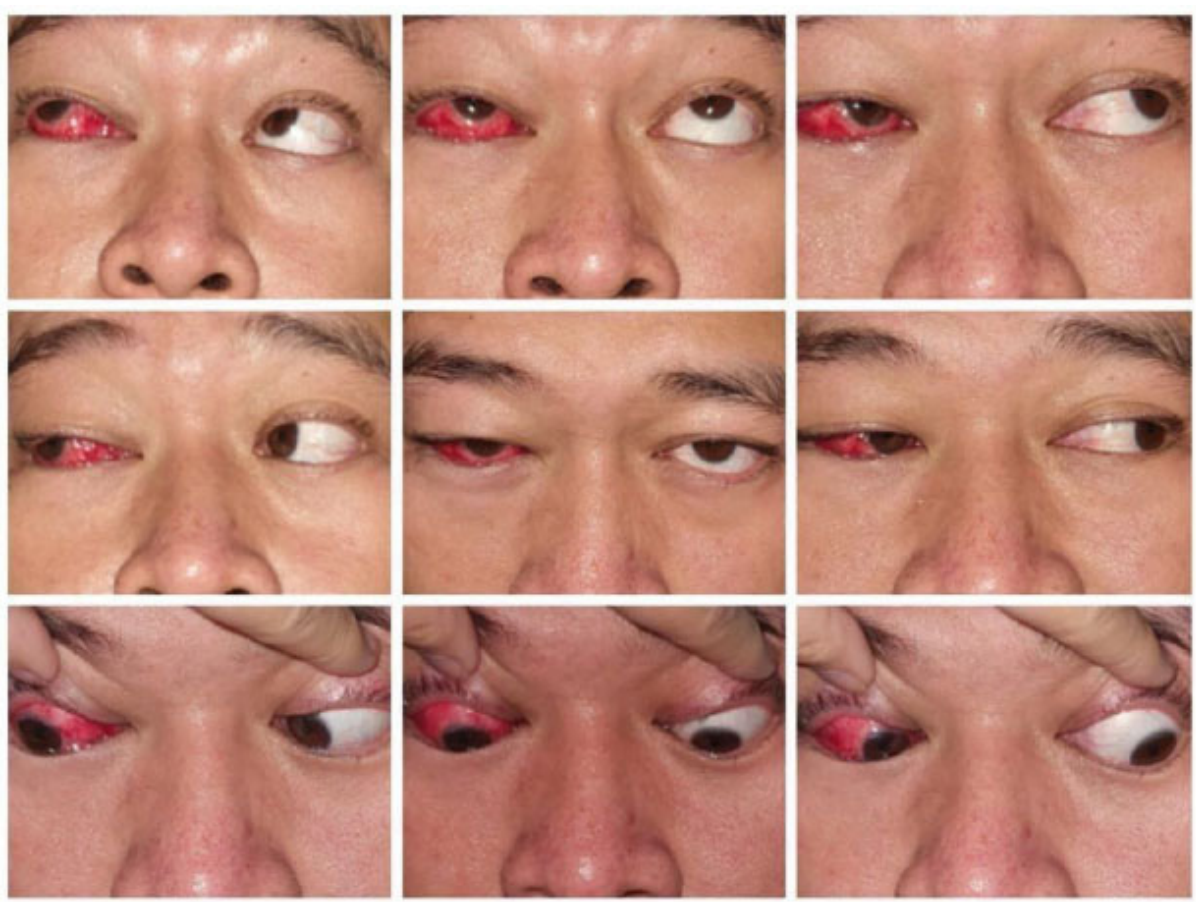

Gambar 9. Gambar nine gaze Post Operasi.

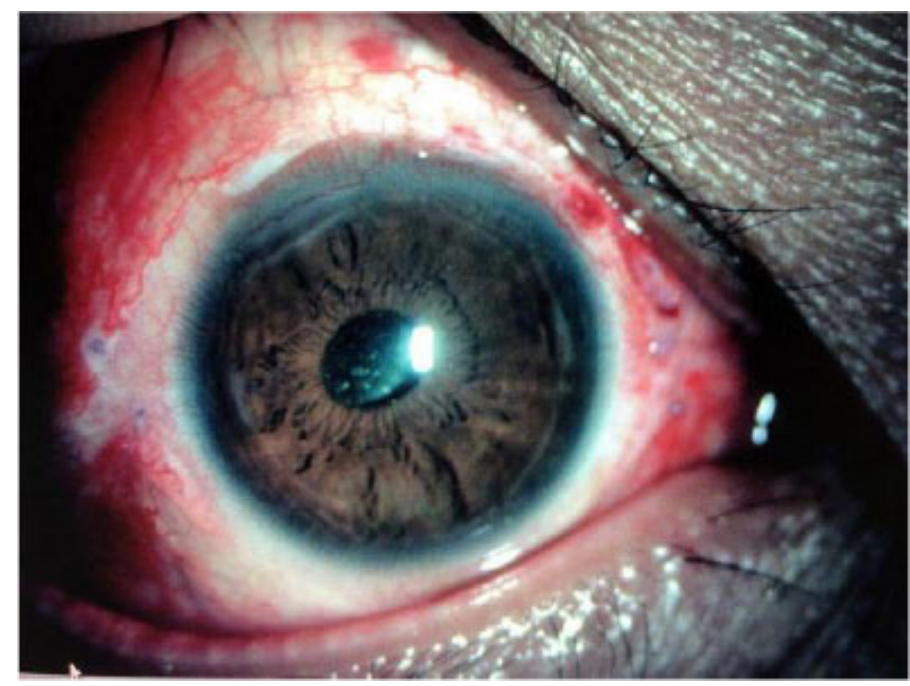

Gambar 10. Gambar anterior 5 hari Post Operasi. sakit dan pandangan seperti tertutup tirai. Gejala lain yang dirasakan adalah floaters, fotopsia (kilatan halilintar kecil pada lapangan pandang), dan gangguan lapang pandang. Untuk pemeriksaan dari funduskopi akan ditemukan retina yang terlepas berwarna pucat dengan pembuluh darah retina yang berkelok-kelok disertai atau tanpa robekan retina. ${ }^{1,6}$

Pernyataan diatas sesuai dengan kasus, dimana ditemukan pada kasus pasien berusia 31 tahun. Pasien juga memiliki riwayat penggunaan kacamata minus dengan ukuran -5.00 D sudah sejak dibangku SMA. Pada pemeriksaan funduskopi retina yang terlepas berwarna pucat disertai pembuluh darah yang berkelok-kelok.

Pemilihan terapi untuk ablasio retina regmatogen dipengaruhi oleh beberapa faktor, salah satunya adalah keahlian dan pertimbangan dari operator. Pemasangan sclera buckle primer bisa dilakukan secara ideal pada orang dengan usia muda, phakia dan pada ablasio retina yang sederhana biasanya lubang pada lattice, lokasinya di inferior dan tanpa adanya PVD. Karena pada kondisi ini traksinya rendah sehingga ukuran break pada retina juga kecil dan progress dari lepasnya retina juga lebih lambat. Kontraindikasi dilakukan pemasangan sclera buckle primer jika ditemukan adanya PVD dan vitreous humor yang cair. ${ }^{3,7}$ Selain itu terdapat pertimbangan melakukan tindakan sclera buckle dikombinasikan dengan vitrektomi. Tindakan kombinasi ini bisa dipertimbangkan saat pre operasi pada pasien muda, phakia, miopia tinggi lebih dari 6 dioptri, panjang bola lebih dari 26 milimeter, adanya proliferative vitreoretinopathy stadium $\mathrm{C}$, break yang multiple di inferior retina, terdapat robekan (break) retina yang luas, dan terjadi robekan berulang. Selain itu, tindakan kombinasi ini bisa dipikirkan dalam intraoperatif ketika menemukan adanya robekan-robekan kecil pada bagian inferior retina atau proliferatif vitreoretinopati dini di bagian inferior retina. ${ }^{3,7}$ Pada pasien ini dilakukan tindakan sclera buckle yang dikombinasikan dengan vitrektomi, dikarenakan pasien muda, phakia, dan riwayat minus tinggi, namun tidak sesuai dengan penjelasan sebelumnya mengenai 
kontraindikasi dilakukan sclera buckle yaitu adanya PVD dan vitreous yang cair.

Tujuan dari pemasangan sclera buckle adalah untuk menghilangkan traksi vitreus dan menutup break pada retina. Penempatan yang tepat dan ketinggian yang sesuai sangat mempengaruhi keberhasilan dalam pemasangan sclera buckle. Prosedur tindakan sclera buckle ini sangat dipengaruhi oleh pengalaman operator untuk menentukan jenis buckle dan keeratan dari jahitan. Jika suatu sclera buckle di ikat dengan erat maka akan mampu mengurangi traksi vitreous dalam jumlah besar namun sering menimbulkan komplikasi berupa munculnya astigmatisme, scleral cheesewiring dan konfigurasi fish mouth. Jika jahitan dilakukan tidak terlalu erat maka akan menyebabkan kegagalan dalam
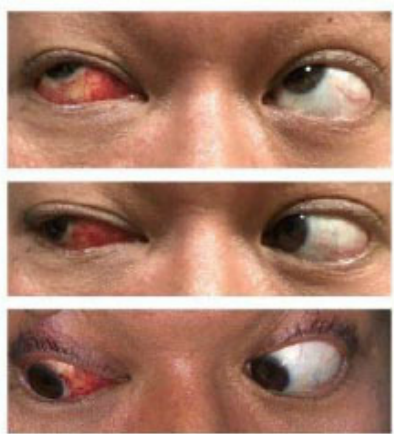
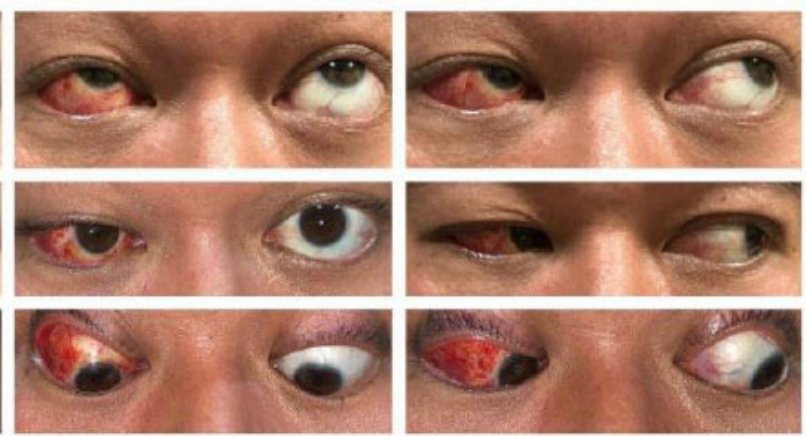

Gambar 11. Gambar nine gaze paska operasi.

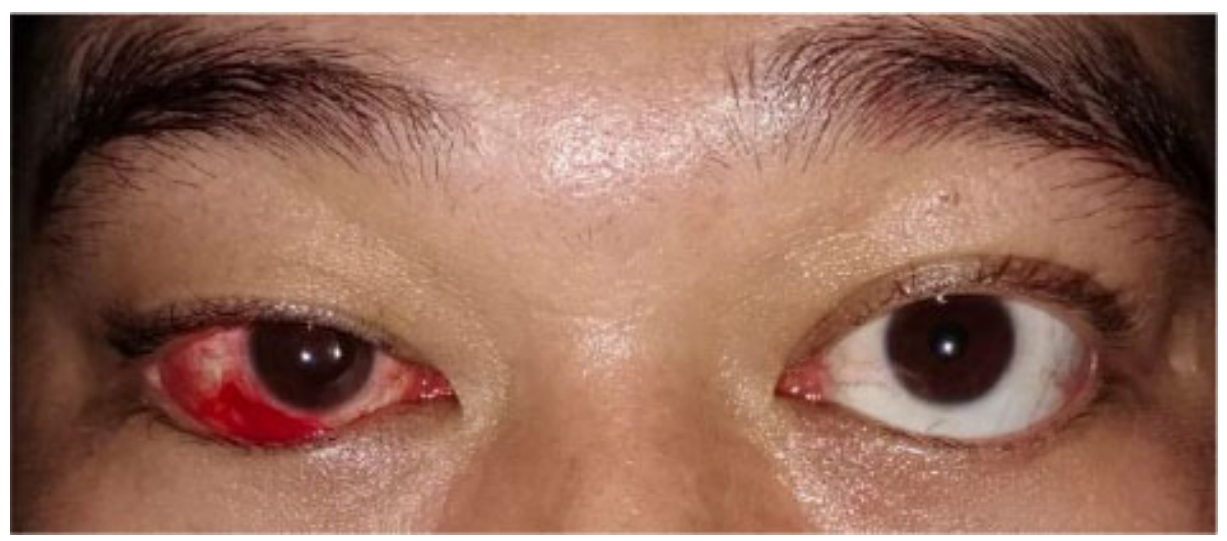

Gambar 12. Foto pasien 1 hari pasca operasi vitrektomi kedua.

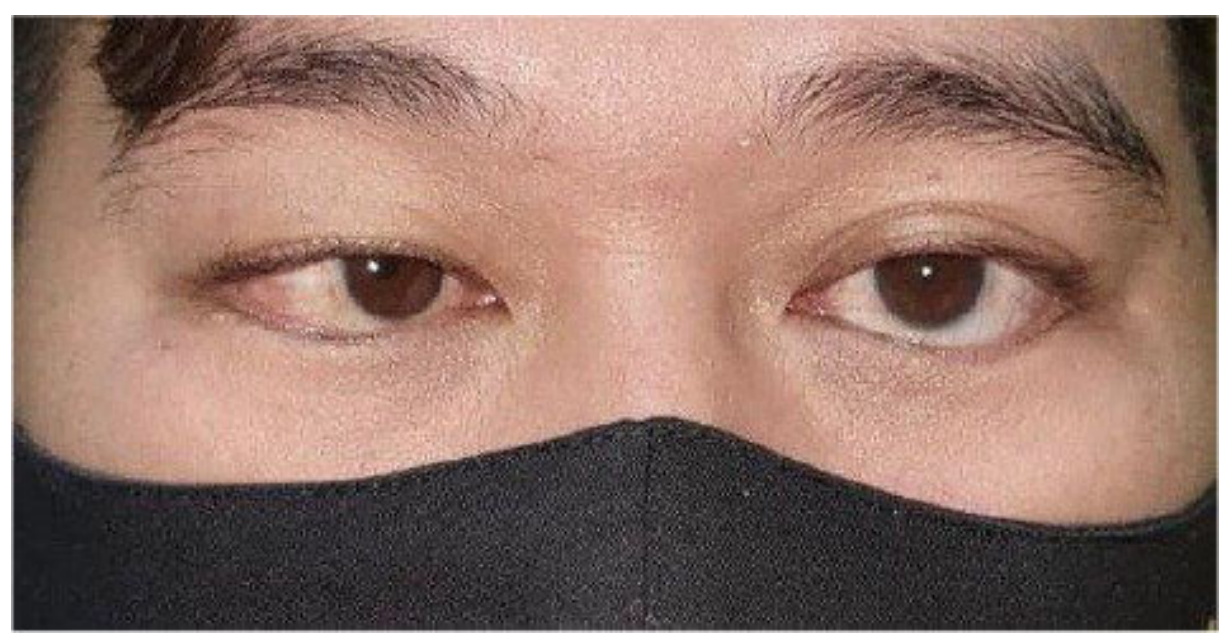

Gambar 13. Foto kondisi mata pasien yang menunjukkan Hirschberg ET 15.

pemasangan sclera buckle.,7

Faktor-faktor penyebab kegagalan penempelan kembali pada retina pada saat pemasangan sclera buckle antara lain kegagalan menemukan break, seperti pada buckle dimana ukurannya, posisi buckle dan tidak adekuatnya ketinggian buckle pada break, dan tekanan gas pada break yang tidak adekuat. Ditemukannya proliferative vitreoretinopathy (PVR) akan menyebabkan kegagalan penempelan kembali pada retina yang terjadi setelah beberapa minggu, prosedur pemasangan sclera buckle dapat dilihat pada gambar 16. ${ }^{3,7}$

Komplikasi dari pemasangan sclera buckle ini adalah salah satunya terjadinya strabismus pasca pemasangan sclera buckle. Kondisi ini bisa terjadi 3-50\% pasien pasca pemasangan sclera buckle dan membaik dalam 6 bulan. ${ }^{8,9}$ Menurut Sunli Ganekal et al, mengatakan insidensi strabismus pasca operasi sclera buckle adalah sebesar $4,65 \% .{ }^{10}$ Menurut akbari et al. Strabismus pasca operasi sclera buckle bisa terjadi akibat 4 mekanisme yaitu sensoris, mekanikal, muskular dan faktor anatomis. Kelainan sensory ini biasanya disebabkan adanya cairan subretina, gangguan penglihatan dan anisometropia akibat dari pemasangan sclera buckle. Kelainan mekanikal akibat pemasangan sclera buckle ini sering terjadi pada kapsul tenon, sklera, septum intramuskular, otot ekstraokuler dan septum orbita. Kerusakan saraf, otot ektopik dan gliosis, dan otot oblik yang berotasi merupakan beberapa faktor anatomis yang juga dapat menyebabkan strabismus pasca pemasangan sclera buckle. ${ }^{5}$ Penyebab tersering dari terjadinya strabismus pasca sclera buckle adalah mekanisme perlekatan di berbagai tempat seperti kapsul tenon, sklera, septum intramuscular, otot ekstraokuler dan lemak orbita. Perlekatan ini biasanya disebabkan oleh terjadinya fibrosis pasca operasi sehingga menyebabkan fat adherence syndrome. ${ }^{11}$ Seperti pada kasus ini saat dilakukan evaluasi otot ekstraokular didapatkan adanya fibrosis pada keempat otot ekstraokular.

Penanganan yang dilakukan jika terjadi strabismus pasca pemasangan sclera buckle ini adalah pemberian injeksi toksin botulinum, kacamata prisma, pelepasan 


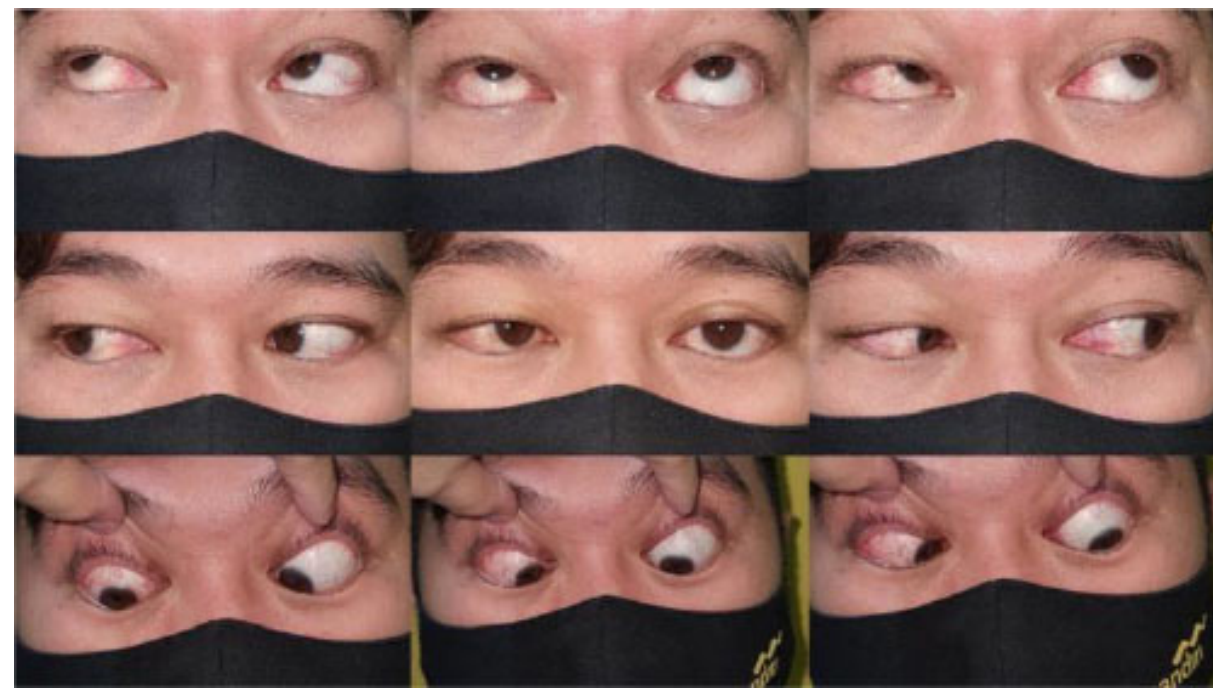

Gambar 14. Foto nine gaze kedudukan bola mata pasien.

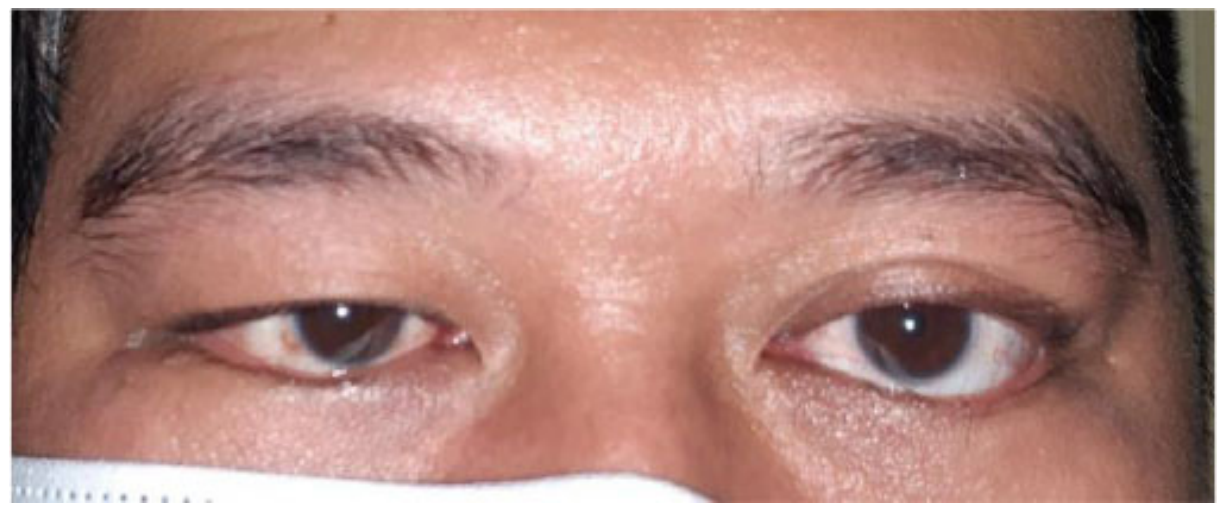

Gambar 15. Foto kondisi mata pasien yang menunjukkan Hirschberg ET 10 derajat.

sclera buckle dan operasi strabismus. Menurut Chang et al, komplikasi strabismus ini bisa membaik apabila sclera buckle dilepas, hal itu dikarenakan otot rektus dapat menempel langsung pada sklera, mengurangi pemanjangan otot rektus ketika terentang pada buckle, membuat otot rektus dapat bergerak lebih bebas, dan ketika buckle dilepas mampu mengembalikan otot-otot rektus yang tidak pada posisinya atau miring. ${ }^{12}$ Menurut Tsui, menyatakan sclera buckle dapat dilepas jika ditemukannya adanya proliferative vitreoretinopathy dan adanya robekan baru. ${ }^{13}$ Penanganan yang dilakukan pada kasus adalah dengan melakukan pelepasan dari sclera buckle dan pembersihan dari fibrosis pada otot ekstraokular.

Penelitian yang dilakukan oleh Rabinowitz et al, dalam penelitian mereka mengatakan tidak didapatkan hasil yang signifikan dalam perbaikan dari strabismus setelah dilakukan pelepasan dari sclera buckle, sehingga diperlukan operasi strabismus lebih lanjut setelah dilakukan pelepasan dari sclera buckle. ${ }^{14,15}$ Penelitian yang dilakukan oleh Osigian et al, menyatakan jika pelepasan dari sclera buckle tidak mampu memberikan hasil yang signifikan dalam memperbaiki keluhan strabismus sehingga memerlukan operasi strabismus lanjutan,selain itu mereka menyatakan jika sclera buckle dilepas maka akan meningkatkan resiko berulang terjadinya ablasio retina. Faktor-faktor yang mempengaruhi tingkat keberhasilan dalam penanganan strabismus setelah operasi sclera buckle menurut Osigian et al, adalah adanya luka pada otot, myotoxicity akibat anestesi peribulbar atau retrobulbar, diseksi sklera, adanya gangguan langsung pada otot yang disebabkan oleh sclera buckle, robekan pada kapsula tenon dan adesi pada orbita fat. ${ }^{16}$ Pada kasus pasien direncanakan untuk dilakukan operasi strabismus lanjutan yaitu medial rectus reses dengan adjustable suture dikarenakan tidak mendapatkan perbaikan dari posisi bola mata setelah dilakukan pelepasan sclera buckle.

\section{SIMPULAN}

Sclera buckle merupakan salah satu tindakan operatif pada ablasio retina regmatogeno. Tindakan sclera buckle ini dapat dikombinasi dengan vitrektomi pada pasien muda, phakia, riwayat miopia tinggi lebih dari 6 dioptri, panjang bola mata lebih dari 26 milimeter, ditemukan adanya proliferative vitreoretinopathy, robekan multiple di bagian inferior retina dan robekan berulang. Pemasangan sclera buckle ini dapat menimbulkan komplikasi berupa strabismus pasca operasi. Penyebab dari terjadinya komplikasi ini salah satunya fibrosis pada otot ekstraokular sehingga terjadi perlekatan yang disebut dengan fat adheren syndrome. Tindakan yang dapat dilakukan untuk penanganan strabismus pasca operasi sclera buckle ini adalah salah satunya dengan pelepasan dari sclera buckle, namun apabila keluhan strabismus tidak membaik bisa dilakukan operasi pada otot ekstraokular untuk memperbaiki posisi bola mata.

\section{KONFLIK KEPENTINGAN}

Penulis menyatakan tidak terdapat konflik kepentingan terkait publikasi dari laporan kasus ini.

\section{PENDANAAN}

Laporan kasus ini tidak mendapatkan pendanaan dari lembaga sektor swasta maupun pemerintah.

\section{ETIKA DALAM PENELITIAN}

Penulis telah mendapatkan informed consent tertulis dari pasien terkait publikasi dari foto klinis dan data medis pada jurnal ilmiah kedokteran dengan tetap menjaga kaidah kerahasian pasien. 

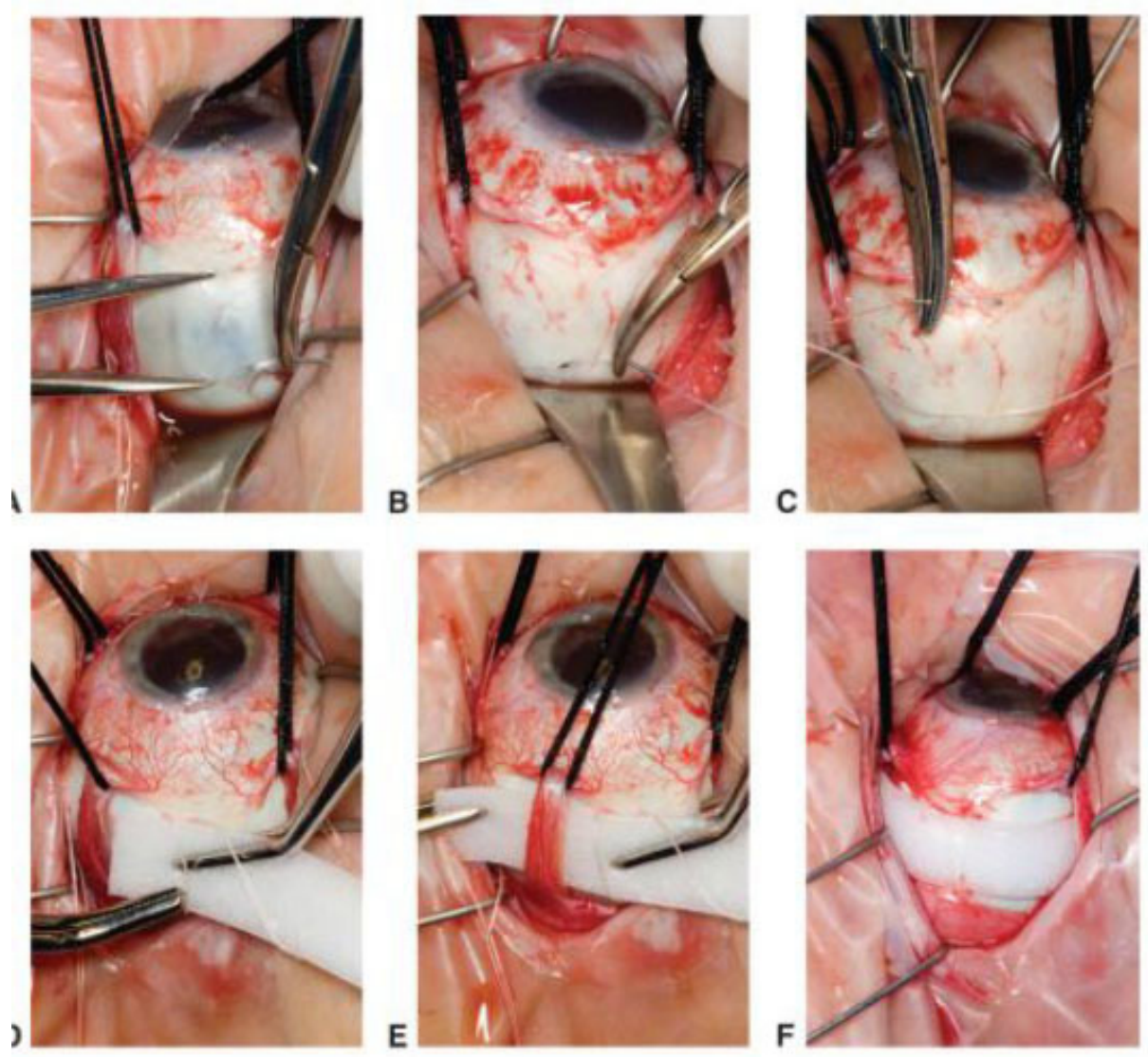

Gambar 16. Prosedur melakukan sclera buckle.

\section{KONTRIBUSI PENULIS}

Seluruh penulis telah berkontribusi terhadap penulisan dari artikel laporan kasus ini dan setuju terhadap versi final untuk dilakukan publikasi.

\section{DAFTAR PUSTAKA}

1. American Academy Of Ophtalmology. Retinal Detachment and Predisposing Lesion. In: Retina and Vitreous. Section 12. San Francisco. 2018. AAO; p.234 - 249.

2. Hamidah Abbas E. Karakteristik Pasien Retinoblastoma Di Pusat Mata Nasional Rumah Sakit Mata Cicendo Bandung Periode Tahun 2012-2016. Med Kartika J Kedokt dan Kesehat. 2018;(Volume 2 No 1):23-35. Available from: http://dx.doi.org/10.35990/mk.v2n1.p23-35

3. Park SW, Lee JJ, Lee JE. Scleral buckling in the management of rhegmatogenous retinal detachment: patient selection and perspectives.
Clin Ophthalmol. 2018;12:1605-15. Available from: https://pubmed.ncbi.nlm.nih. gov/30214145

4. Spandau U, Tomic Z, Casas RD. Retinal Detachment Surgery and Proliferative Vitreoretinopathy [Internet]. Springer International Publishing; 2018. Available from: http://dx.doi.org/10.1007/978-3-319-78446-5

5. Akbari MR, Mirmohammadsadeghi A, Makateb A, Ghassemi F, Norooznezhad AH, Khodabande A, et al. Ocular movement disorders following scleral buckling surgery: A case series study. J Curr Ophthalmol. 2018;31(2):195-200. Available from: https:// pubmed.ncbi.nlm.nih.gov/31317099

6. Haddock LJ, Lyttle DP, Rosenfeld PJ. Extrascleral Vitreous Prolapse Following Intravitreal Injection. J Vitreoretin Dis. 2017;1(6):428-30. Available from: http://dx.doi. org/10.1177/2474126417732931

7. Chronopoulos A. Complications of Encircling Bands-Prevention and Management. J Clin
Exp Ophthalmol. 2015;06(03). Available from: http://dx.doi.org/10.4172/2155-9570.1000440

8. Koç AA. Results of Scleral Buckling Surgery in Rhegmatogenous Retinal Detachment. Beyoglu Eye J. 2017; Available from: http://dx.doi. org/10.14744/bej.2017.09719

9. Papakostas TD, Vavvas D. Postoperative Complications of Scleral Buckling. Semin Ophthalmol. 2017;33(1):70-4. Available from: http://dx.doi.org/10.1080/08820538.2017.1353 816

10. Ganekal S, Nagarajappa A. Strabismus Following Scleral Buckling Surgery. Strabismus. 2016;24(1):16-20. Available from: http://dx.doi. org/10.3109/09273972.2015.1130066

11. Wu TJ, Rosenbaum AL, Demer JL. Severe strabismus after scleral buckling. Ophthalmology.2005;112(2):327-36. Available from: http://dx.doi.org/10.1016/j. ophtha.2004.09.015

12. Chang JH, Hutchinson A, Zhang M, Lambert SR. Effect of scleral buckle removal on strabismus surgery outcomes after retinal detachment repair. J Am Assoc Pediatr Ophthalmol Strabismus. 2012;16(1):e12. Available from: http://dx.doi.org/10.1016/j. jaapos.2011.12.048

13. Tsui I. Scleral Buckle Removal: Indications and Outcomes. Surv Ophthalmol. 2012;57(3):25363.Available from: http://dx.doi.org/10.1016/j. survophthal.2011.11.001

14. Rabinowitz R, Velez FG, Pineles SL. Risk factors influencing the outcome of strabismus surgery following retinal detachment surgery with scleral buckle. J AAPOS Off Publ Am Assoc Pediatr Ophthalmol Strabismus. 2013/11/09. 2013;17(6):594-7. Available from: https:// pubmed.ncbi.nlm.nih.gov/24215808

15. Kumar P, Hoover DL, Lambert SR. Partial scleral buckle removal during strabismus surgery after retinal detachment repair. J Am Assoc Pediatr Ophthalmol Strabismus. 2019;23(1):16.e1-16. e4. Available from: http://dx.doi.org/10.1016/j. jaapos.2018.08.011

16. Osigian CJ, Rothfield L, Rabina G, Cavuoto KM, Spierer O, Vanner EA, et al. Strabismus surgery outcomes without removal of scleral buckle in patients with previous retinal detachment repair. J Am Assoc Pediatr Ophthalmol Strabismus. 2018;22(4):272-275. e1. Available from: http://dx.doi.org/10.1016/j. jaapos.2018.04.004

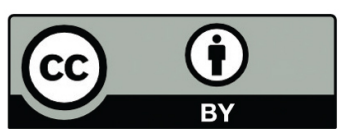

This work is licensed under a Creative Commons Attribution 